\title{
PENGARUH STRUKTUR MODAL, PERTUMBUHAN PERUSAHAAN, PROFITABILITAS DAN UKURAN PERUSAHAAN TERHADAP NILAI PERUSAHAAN
}

(Studi pada Perusahaan Manufaktur Di Indonesia)

\author{
Oleh : \\ Eli Safrida \\ (Dosen Politeknik Negeri Medan)
}

\begin{abstract}
The purpose of this study was to examine the effect of capital structure, corporate growth, profitability and firm size on firm value in manufacturing companies in Indonesia Stock Exchange. The population in this study were all manufacturing companies listed in Jakarta Stock Exchange with a study period of 2006 through to 2009, amounted to 151 companies. Samples were selected using purposive sampling method amounted to 115 companies. Mechanical testing data is by using simple linear regression to test the partial and multiple linear regression to simultaneously test, with significance level alpha of 5\%. The results of this study partially proves that the capital structure in a positive and significant effect on the value of the company, growth company in a positive effect but no significant effect on corporate value, profitability and significant positive effect on firm value, firm size and a significant negative effect on firm value. Simultaneously prove that the capital structure, corporate growth, profitability, firm size have a significant effect on firm value.
\end{abstract}

Keywords: capital structure, corporate growth, profitability, firm size and firm value.

\section{Latar Belakang}

Keputusan pendanaan berkaitan dengan pemilihan sumber dana baik yang berasal dari dalam maupun dari luar perusahaan yang sangat mempengaruhi nilai perusahaan. Sumber dana perusahaan dari internal berasal dari laba ditahan dan depresiasi. Sumber dana eksternal perusahaan berasal dari kreditur pemenuhan kebutuhan dana yang berasal dari para kreditur merupakan hutang bagi perusahaan. Dana yang diperoleh dari para pemilik merupakan modal sendiri.

Tujuan perusahaan dalam jangka panjang adalah mengoptimalkan nilai perusahaan dengan meminimumkan biaya modal perusahaan. Semakin tinggi nilai perusahaan menggambarkan semakin sejahtera pemilik perusahaan. Penggunaan kebijakan hutang bisa digunakan untuk menciptakan nilai perusahaan yang diinginkan, namun kebijakan hutang juga tergantung dari pertumbuhan perusahaan yang juga terkait dengan ukuran perusahaan. Artinya perusahaan yang besar dan memiliki tingkat pertumbuhan perusahaan yang baik relatif lebih mudah untuk mengakses ke pasar modal. Kemudahan ini mengindikasikan bahwa perusahaan besar relatif mudah memenuhi sumber dana dari hutang melalui pasar modal, perusahaan yang memiliki tingkat pertumbuhan perusahaan yang baik menunjukkan kemampuan perusahaan untuk membayar bunga hutang jika menggunakan hutang untuk menjalankan operasional perusahaan tersebut. Oleh karena itu, mengkaitkan struktur modal dengan pertumbuhan perusahaan dan nilai perusahaan menjadi relevan.

Weston dan Brigham (1985:174) mengartikan bahwa struktur keuangan (financial leverage) merupakan cara aktiva-aktiva perusahaan dibelanjai/ dibiayai; hal ini seluruhnya merupakan bagian kanan neraca, sedangkan struktur modal (capital structure) merupakan pembiayaan pembelanjaan permanen perusahaan, yang terutama berupa hutang jangka panjang, saham preferen/ prioritas dan modal saham biasa, tetapi tidak semua masuk kredit jangka pendek. Jadi struktur modal dalam suatu perusahaan adalah hanya sebagian dari struktur keuangannya.

Prinsip manajemen perusahaan menuntut agar baik dalam memperoleh maupun menggunakan dana harus didasarkan pada efesiensi dan efektifitas. Efesiensi penggunaan dana berarti bahwa berapa pun dana yang ditanamkan dalam aktiva harus dapat digunakan seefesiensi mungkin untuk menghasilkan tingkat keuntungan investasi yang maksimal. Fungsi penggunaan 
dana meliputi perencanaan dan pengendalian penggunaan aktiva dalam aktiva lancar maupun aktiva tetap, agar dana yang tertanam dalam masing-masing unsur aktiva tersebut disatu pihak tidak terlalu kecil jumlahnya, sehingga tidak dapat mengganggu likuiditas dan kelanjutan usaha, dan di lain pihak tidak terlalu besar jumlahnya sehingga menimbulkan pengangguran dana. Oleh karena itu, pengalokasian dana harus didasarkan pada perencanaan yang tepat, sehingga dana yang menganggur menjadi kecil. Efesiensi penggunaan dana secara langsung dan tidak langsung akan menentukan besar kecilnya tingkat keuntungan yang dihasilkan dari investasi.

Manajer keuangan harus bijaksana dalam menjalankan fungsi penggunaan dana yang selalu dituntut untuk mencari alternatif investasi kemudian dianalisis dan hasil analisis tersebut harus dapat diambil keputusan alternatif investasi mana yang akan dipilih. Dengan kata lain, manajer harus mengambil keputusan investasi. Menurut trade off theory manajer dapat memilih rasio utang untuk memaksimalkan nilai perusahaan. Fama (1978) berpendapat bahwa nilai perusahaan akan tercermin dari harga pasar saham. Jensen (2001) menjelaskan bahwa untuk memaksimalkan nilai perusahaan tidak hanya dengan nilai ekuitas saja yang harus diperhatikan, tetapi juga semua sumber keuangan seperti hutang, warran, maupun saham preferen.

Fama dan French (1998) berpendapat bahwa optimalisasi nilai perusahaan yang merupakan tujuan perusahaan dapat dicapai melalui fungsi manajemen keuangan, dimana satu keputusan keuangan yang diambil akan mempengaruhi keputusan keuangan lainnya dan berdampak pada nilai perusahaan. Nilai pasar perusahaan merupakan nilai pasar dari suatu ekuitas perusahaan ditambah nilai pasar hutang (Helfert, 1997: 335). Dengan demikian, penambahan dari jumlah ekuitas perusahaan dengan hutang perusahaan dapat mencerminkan nilai perusahaan. Diperkirakan berdasarkan penelitian terdahulu, ada beberapa faktor yang dapat mempengaruhi nilai perusahaan, diantaranya: keputusan pendanaan, kebijakan deviden, keputusan investasi, struktur modal, pertumbuhan perusahaan, ukuran perusahaan. Dimana, beberapa faktor tersebut memiliki hubungan dan pengaruh terhadap nilai perusahaan yang tidak konsisten. Nilai perusahaan adalah nilai laba masa yang akan datang yang diekspektasi yang dihitung kembali dengan suku bunga yang tepat (Winardi, 2001:23).

Teori struktur modal menjelaskan pengaruh struktur modal terhadap nilai perusahaan. Nilai perusahaan dapat diartikan sebagai ekspektasi nilai investasi pemegang saham (harga pasar ekuitas) dan/ atau ekspektasi nilai total perusahaan (harga pasar ekuitas ditambah dengan nilai pasar hutang, atau ekspektasi harga pasar aktiva (Sugihen, 2003: 28).

Pertumbuhan (Growth) adalah seberapa jauh perusahaan menempatkan diri dalam sistem ekonomi secara keseluruhan atau sistem ekonomi untuk industri yang sama (Machfoedz, 1996: 108). Pada umumnya, perusahaan yang tumbuh dengan cepat memperoleh hasil positif dalam artian pemantapan posisi di peta persaingan, menikmati penjualan yang meningkat secara signifikan dan diiringi oleh adanya peningkatan pangsa pasar. Perusahaan yang tumbuh cepat juga menikmati keuntungan dari citra positif yang diperoleh, akan tetapi perusahaan harus ekstra hatihati, karena kesuksesan yang diperoleh menyebabkan perusahaan menjadi rentan terhadap adanya isu negatif. Beberapa hal yang perlu mendapat perhatian penting karena dapat merupakan sumber berita negatif yang menggambarkan kemampuan perusahaan untuk mempertahankan, mengembangkan dan membangun kecocokan kualitas dan pelayanan dengan harapan konsumen. Pertumbuhan cepat juga memaksa sumber daya manusia yang dimiliki untuk secara optimal memberikan kontribusinya. Agar pertumbuhan cepat tidak memiliki arti pertumbuhan biaya yang kurang terkendali, maka dalam mengelola pertumbuhan, perusahaan harus memiliki pengendalian operasi dengan penekanan pada pengendalian biaya (Susanto, 1997: 185-187).

Ukuran perusahaan adalah salah satu faktor yang menentukan nilai perusahaan. Semakin besar kemampuan dan sumber dana yang dimiliki akan menunjukkan bahwa perusahaan tersebut akan semakin baik. Kemampuan finansial perusahaan besar menjadikannya lebih dipercaya oleh lembaga keuangan, sehingga perusahaan besar memiliki akses lebih besar untuk memperoleh pinjaman. Dengan demikian perusahaan besar tersebut dapat lebih berkembang, sehingga pemegang saham tidak memiliki kekuasaan penuh terhadap perusahaan.

Profitabilitas adalah kemampuan perusahaan memperoleh laba dalam hubungannya dengan penjualan, total aktiva maupun modal sendiri. Dengan demikian bagi investor jangka panjang akan sangat berkepentingan dengan analisa profitabilitas (Sartono, 2001:122). 
Beberapa penelitian yang terkait dengan struktur modal yang mempengaruhi nilai perusahaan telah banyak dilakukan oleh peneliti. Sugihen (2003) menemukan bukti bahwa struktur modal berpengaruh tidak langsung negatif terhadap nilai perusahaan.Wahyudi dan Hartini (2004) yang membuktikan bahwa Keputusan pendanaan berpengaruh terhadap nilai perusahaan, tetapi keputusan investasi dan kebijakan deviden tidak berpengaruh terhadap nilai perusahaan.Solihah dan Taswan (2002) menemukan bukti bahwa kebijakan hutang berpengaruh positif namun tidak signifikan terhadap nilai perusahaan. Hasil penelitian ini konsisten dengan temuan Modigliani and Miller pada tahun 1963 bahwa dengan memasukkan pajak penghasilan perusahaan, maka penggunaan hutang akan meningkatkan nilai perusahaan.Hasnawati (2005) membuktikan bahwa Kebijakan deviden secara langsung mempengaruhi nilai perusahaan dan secara tidak langsung keputusàn investasi mempengaruhi nilai perusahaan melalui kebijakan deviden dan keputusan pendanaan.Sriwardany (2006) menemukan bukti bahwa struktur modal mempunyai pengaruh negatif terhadap perubahan harga saham. Safrida (2008) menemukan bukti bahwa Struktur modal berpengaruh negatif dan signifikan terhadap nilai perusahaan. Penelitian yang berhubungan dengan pengaruh pertumbuhan perusahaan terhadap nilai perusahaan ditemukan oleh Sriwadany (2006) pertumbuhan perusahaan mempunyai pengaruh yang langsung terhadap harga saham.Rahmawati dan Akram (2004) yang menemukan bukti bahwa pertumbuhan laba berpengaruh negatif terhadap nilai perusahaan tetapi tidak signifikan. Safrida (2008) pertumbuhan perusahaan berpengaruh negatif namun tidak signifikan terhadap nilai perusahaan. Penelitian yang terkait dengan ukuran perusahaan dilakukan oleh Rahmawati dan Akram (2004) menemukan bukti bahwa ukuran perusahaan pengaruh negatif terhadap nilai perusahaan tetapi tidak signifikan.

\section{Rumusan Masalah}

Berdasarkan uraian latar belakang diatas, maka rumusan masalah dalam penelitian ini adalah bagaimana Pengaruh Struktur Modal, Pertumbuhan Perusahaan, Profitabilitas Dan Ukuran Perusahaan Terhadap Nilai Perusahaan pada perusahaan manufaktur di Indonesia.

\section{Kerangka Pemikiran}

Struktur modal adalah pembelanjaan permanen didalam mencerminkan perimbangan antara hutang jangka panjang dengan modal sendiri. Struktur modal tercermin pada hutang jangka panjang dan unsur-unsur modal sendiri, dimana kedua golongan tersebut merupakan dana permanen atau dana jangka panjang. Dengan demikian maka struktur modal hanya merupakan sebagian saja dari struktur financial. Struktur financial mencerminkan perimbangan baik dalam artian absolut maupun relatif antara keseluruhan modal asing (baik jangka pendek maupun jangka panjang) dengan jumlah modal sendiri (Riyanto, 1999:22).

Struktur modal merupakan kombinasi hutang dan ekuitas dalam struktur keuangan jangka panjang perusahaan. Tidak seperti debt ratio atau leverage ratio yang hanya menggambarkan target komposisi hutang dan ekuitas dalam jangka panjang pada suatu perusahaan (Arifin, 2005:77)

Teori struktur modal menjelaskan apakah ada pengaruh perubahan struktur modal terhadap nilai perusahaan, jika keputusan investasi dan kebijakan deviden dipegang konstan. Dengan kata lain, jika perusahaan menggantikan sebagian modal sendiri dengan hutang atau sebaliknya apakah harga saham akan berubah, apabila perusahaan tidak merubah keputusankeputusan keuangan lainnya. Dengan kata lain, seandainya perubahan struktur modal tidak merubah nilai perusahaan, berarti bahwa tidak ada struktur modal yang terbaik. Semua struktur modal adalah baik. Tetapi kalau dengan merubah struktur modal ternyata nilai perusahaan berubah, maka akan diperoleh struktur modal yang terbaik. Struktur modal yang akan memaximumkan nilai perusahaan adalah struktur modal yang terbaik (Husnan, 2004: 263).

Teori struktur modal adalah teori yang menjelaskan bahwa kebijakan pendanaan perusahaan dalam menentukan bauran antara hutang dan ekuitas yang bertujuan untuk memaximumkan nilai perusahaan. Setiap keputusan pendanaan mengharuskan manajer keuangan untuk dapat mempertimbangkan manfaat dan biaya dari sumber-sumber dana yang akan dipilih .

Sumber pendanaan didalam perusahaan dibagi kedalam dua kategori, yaitu sumber pendanaan internal dan sumber pendanaan eksternal. Sumber pendanaan internal dapat diperoleh 
dari laba ditahan dan depresiasi aktiva tetap sedangkan sumber pendanaan eksternal dapat diperoleh dari para kreditur yang disebut dengan hutang.

Pada tahun 1958 Modigliani dan Miller (MM) menunjukkan bukti bahwa nilai suatu perusahaan tidak dipengaruhi oleh struktur modal, bukti tersebut dengan berdasarkan serangkaian asumsi antara lain, tidak ada biaya broker (pialang), tidak ada pajak, tidak ada biaya kebangkrutan, para investor dapat meminjam dengan tingkat suku bunga yang sama dengan perseroan, semua investor mempunyai informasi yang sama, EBIT tidak dipengaruhi oleh biaya hutang. Dengan hasil tersebut menunjukkan kondisi-kondisi di mana struktur modal tidak relevan, MM juga memberikan petunjuk agar struktur modal menjadi relevan sehingga akan mempengaruhi nilai perusahaan (Brigham dan Houston, 2001: 31).

Pada tảhun 1963 MM menerbitkan makalah lanjutan yang melemahkan asumsi tidak ada pajak perseroan. Peraturan perpajakan memperbolehkan pengurangan pembayaran bunga sebagai beban, tetapi pembayaran dividen kepada pemegang saham tidak dapat dikurangkan. Hasil penelitiannya mendorong perusahaan untuk menggunakan hutang dalam struktur modal. Kesimpulan ini diubah oleh Miller ketika memasukkan efek dari pajak perseorangan, Miller berpendapat bahwa investor bersedia menerima pengembalian atas saham sebelum pajak yang relatif rendah dibandingkan dengan pengembalian atas obligasi sebelum pajak (Brigham dan Houston, 2001: 32).

Hasil-hasil MM yang tidak relevan juga tergantung pada asumsi tidak adanya biaya kebangkrutan. Perusahaan yang bangkrut mempunyai biaya hukum dan akuntansi yang sangat tinggi, dan mereka juga sulit untuk menahan pelanggan, pemasok dan karyawan. Bahkan, kebangkrutan sering memaksa suatu perusahaan untuk melikuidasi atau menjual hartanya dengan harga dibawah harga seandainya perusahaan beroperasi. Biaya yang terkait dengan kebangkrutan, yaitu: (1) proftabilitas terjadinya, (2) biaya-biaya yang akan timbul bila kesulitan keuangan akan muncul. Perusahaan yang labanya lebih labil, bila semua hal lain sama, menghadapi biaya kebangkrutan yang lebih besar sehingga harus menggunakan lebih sedikit hutang daripada perusahaan yang stabil (Brigham dan Houston, 2001: 33).

Teori trade-off dari leverage adalah teori yang menjelaskan bahwa struktur modal yang optimal ditemukan dengan menyeimbangkan manfaat dari pendanaan dengan hutang (perlakukan pajak perseroan yang menguntungkan) dengan suku bunga dan biaya kebangkrutan yang lebih tinggi (Brigham dan Houston, 2001: 34). Biaya dari hutang dihasilkan dari (1) peningkatan kemungkinan kebangkrutan yang disebabkan oleh kewajiban hutang yang tergantung pada tingkat risiko bisnis dan risiko keuangan. (2) biaya agen dan pengendalian tindakan perusahaan. (3) biaya yang berkaitan dengan manajer yang mempunyai informasi lebih banyak tentang prospek perusahaan daripada investor (Sriwardany, 2006: 16).

Jika pendekatan Modigliani dan Miller dalam kondisi ada pajak penghasilan perusahaan, maka nilai perusahaan akan meningkat terus karena penggunaan hutang yang semakin besar. Tetapi perlu diingat bahwa nilai sekarang dari financial distress dan nilai sekarang agency cost dapat mengakibatkan menurunnya nilai perusahaan yang memiliki leverage (Sartono, 2001: 246).

Berdasarkan teori dan kerangka pemikiran diatas, maka hipotesis dalam penelitian ini adalah sebagai berikut:

$\mathrm{H}_{1}$ : Struktur modal berpengaruh terhadap nilai perusahaan

$\mathrm{H}_{2}$ : Pertumbuhan perusahaan berpengaruh terhadap nilai perusahaan

$\mathrm{H}_{3}$ : Profitabilitas berpengaruh terhadap nilai perusahaan

$\mathrm{H}_{4}$ : Ukuran perusahaan berpengaruh terhadap nilai perusahaan

$\mathrm{H}_{5}$ : Struktur modal, pertumbuhan perusahaan, profitabilitas, ukuran perusahaan berpegaruh terhadap nilai perusahaan

\section{Metode Penelitian}

Sesuai dengan tujuan penelitian yaitu menguji hipotesis, maka desain penelitian yang digunakan dalam penelitian ini adalah desain kausal. Penentuan populasi dalam penelitian ini adalah seluruh perusahaan manufaktur di Bursa Efek Jakarta. Berdasarkan informasi yang diperoleh dari Indonesian Capital Market Directory (www.idx.com) jumlah perusahaan manufaktur yang terdaftar tahun 2009 adalah 151 perusahaan. 
Penentuan sampel dalam penelitian ini berdasarkan pada metode purposive sampling, dimana sampel perusahaan dipilih berdasarkan pada kriteria tertentu. Adapun kriteria yang digunakan untuk memilih sampel adalah perusahaan manufaktur yang terdaftar di Bursa Efek Jakarta sesuai dengan pengklasifikasian Indonesian Capital Market Directoryang Perusahaan manufaktur yang menerbitkan laporan keuangan dari tahun 2006-2009 secara berturut-turut: Adapun proses pengambilan sampelnya adalah sebagai berikut:

Tabel 1. Proses Pengambilan Sampel

\begin{tabular}{|l|r|}
\hline Perusahaan manufaktur yang terdaftar dari tahun 2006 - 2009 & 151 \\
\hline $\begin{array}{l}\text { Perusahaan manufaktur yang tidak berturut-turut menerbitkan laporan keuangan per } 31 \\
\text { Desember 2006 - 31 Desember 2009 }\end{array}$ & 36 \\
\hline Jumlah Perusahaan & 115 \\
\hline
\end{tabular}

Variabel Penelitian

Dalam penelitian ini, yang dijadikan sebagai variabel dependen adalah niai perusahaan $(\mathrm{Y})$. Sedangkan variabel independen dalam penelitian ini adalah struktur modal $\left(\mathrm{X}_{1}\right)$, pertumbuhan perusahaan $\left(\mathrm{X}_{2}\right)$, profitabilitas $\left(\mathrm{X}_{3}\right)$, ukuran perusahaan $\left(\mathrm{X}_{4}\right)$.

\section{Nilai Perusahaan (Y)}

Nilai perusahaan diukur dengan Market to Book Ratio (MBR). Market to Book Ratio adalah perbandingan antara harga pasar perlembar saham terhadap nilai buku ekuitas perlembar saham (Brigham and Gapenski, 1998:780).

Struktur Modal $\left(\mathbf{X}_{1}\right)$

Struktur modal merupakan perbandingan total hutang yang dimiliki perusahaan terhadap total ekuitas perusahaan. Struktur Modal diukur dengan Debt to Equity Ratio (DER). Debt to Equity Ratio adalah suatu upaya untuk memperlihatkan, dalam format lain, proporsi relatif dari klaim pemberi pinjaman terhadap hak kepemilikan, dan digunakan sebagai ukuran peranan hutang (Helfert, 1997: 98-99).

\section{Pertumbuhan Perusahaan $\left(\mathrm{X}_{2}\right)$}

Pertumbuhan perusahaan diukur dengan menggunakan perubahan total aktiva. Pertumbuhan perusahaan adalah selisih total aktiva yang dimiliki oleh perusahaan pada periode sekarang dengan periode sebelumnya terhadap total aktiva periode sebelumnya.

\section{Profitabilitas $\left(\mathrm{X}_{3}\right)$}

Profitabilitas diukur dengan menggunakan selisih antara penjualan dengan harga pokok penjualan terhadap penjualan. Profitabilitas adalah kemampuan perusahaan memperoleh laba dalam hubungannya dengan penjualan (Santoso, 2001:122).

Ukuran Perusahaan $\left(\mathbf{X}_{4}\right)$

Ukuran perusahaan menunjukkan besaran suatu perusahaan. Ukuran perusahaan dapat di ukur dengan proxy nilai logaritma natural dari total aktiva.

\section{Teknik dan Model Analisis}

Teknik analisis data yang dilakukan dalam penelitian ini adalah menggunakan model regresi. Untuk dapat melakukan analisis dengan model regresi, data harus good and fit. Penilaian good and fit dianalisis dengan uji kualitas data. Adapun uji kualitas data terdiri dari statistik deskriptif dan asumsi klasik. Pengujian asumsi klasik di mulai dengan melakukan uji normalitas, uji autokorelasi, uji multikolinearitas dan uji heterokedastisitas.

Pengujian hipotesis dalam penelitian ini akan menguji apakah struktur modal, pertumbuhan perusahaan, profitabilitas, ukuran perusahaan berpengaruh terhadap nilai perusahaan. Teknik statistik yang digunakan adalah regresi linier. Pengujian hipotesis dengan menggunakan model regresi sederhana diterapkan untuk hipotesis $1,2,3,4$ karena hanya menguji pengaruh secara parsial antara variabel independen (struktur modal, pertumbuhan perusahaan, propitabilitas, ukuran perusahaan) terhadap satu variabel dependen (nilai perusahaan). 
Apabila nilai koefisien struktur modal yang diukur dengan debt to equity rasio (DER) signifikan, maka akan menunjukkan bahwa struktur modal berpengaruh terhadap nilai perusahaan. Nilai koefisien pertumbuhan perusahaan yang diukur dengan perubahan total aktiva yang signifikan menunjukkan bahwa terdapat pengaruh antara pertumbuhan perusahaan terhadap nilai perusahaan. Nilai koefisien profitabilitas yang diukur dengan gross profit margin yang signifikan menunjukkan bahwa terdapat pengaruh antara profitabilitas terhadap nilai perusahaan. Nilai koefisien ukuran perusahaan yang diukur dengan LN total aktiva yang signifikan menunjukkan bahwa terdapat pengaruh antara ukuran perusahaan terhadap nilai perusahaan.

Pengujian hipotesis 1 apakah struktur modal berpengaruh terhadap nilai perusahaan, dapat dilakukan dengan teknik regresi linier sederhana. Adapun langkah-langkah yang dilakukan sebagai berikut:

1. Membuat Formulasi Hipotesis:

$\mathrm{H}_{1:} \mathrm{b}_{1} \neq 0$, struktur modal berpengaruh terhadap nilai perusahaan

2. Menentukan Tingkat Signifikansi.

Untuk memperoleh nilai signifikansi, menggunakan taraf nyata $(\alpha) 5 \%$.

3. Dasar pengambilan keputusan

a. $\rho$-value $<0.05$, maka $\mathrm{H}_{1}$ berpengaruh

b. $\rho$-value $>0.05$, maka $\mathrm{H}_{1}$ tidak berpengaruh

Pengujian hipotesis 2 apakah pertumbuhan perusahaan berpengaruh terhadap nilai perusahaan, dapat dilakukan dengan teknik regresi linier sederhana. Adapun langkah-langkah yang dilakukan sebagai berikut:

1. Membuat Formulasi Hipotesis:

$\mathrm{H}_{2}: b_{2} \neq 0$, pertumbuhan perusahaan berpengaruh terhadap nilai perusahaan

2. Menentukan Tingkat Signifikasi.

Untuk memperoleh nilai signifikansi, menggunakan taraf nyata $(\alpha) 5 \%$.

3. Dasar pengambilan keputusan

a. $\rho$-value $<0.05$, maka $\mathrm{H}_{2}$ berpengaruh

b. $\rho$-value $>0.05$, maka $\mathrm{H}_{2}$ tidak berpengaruh

Pengujian hipotesis 3 apakah profitabilitas berpengaruh terhadap nilai perusahaan, dapat dilakukan dengan teknik regresi linier sederhana. Adapun langkah-langkah yang dilakukan adalah sebagai berikut:

1. Membuat Formulasi Hipotesis:

$\mathrm{H}_{3}: \mathrm{b}_{3} \neq 0$, profitabilitas berpengaruh terhadap nilai perusahaan

2. Menentukan Tingkat Signifikansi

Untuk memperoleh nilai signifikansi, menggunakan taraf nyata $(\alpha) 5 \%$.

3. Dasar pengambilan keputusan

a. $\rho$-value $<0.05$, maka $\mathrm{H}_{3}$ berpengaruh

b. $\rho$-value $>0.05$, maka $\mathrm{H}_{3}$ tidak berpengaruh

Pengujian hipotesis 4 apakah ukuran perusahaan berpengaruh terhadap nilai perusahaan, dapat dilakukan dengan teknik regresi linier sederhana. Adapun langkah-langkah yang dilakukan sebagai berikut:

1. Membuat Formulasi Hipotesis:

$\mathrm{H}_{4}: \mathrm{b}_{4} \neq 0$, pertumbuhan perusahaan berpengaruh terhadap nilai perusahaan

2. Menentukan Tingkat Signifikasi.

Untuk memperoleh nilai signifikansi, menggunakan taraf nyata $(\alpha) 5 \%$.

3. Dasar pengambilan keputusan

a. $\rho$-value $<0.05$, maka $\mathrm{H}_{4}$ berpengaruh

b. $\rho$-value $>0.05$, maka $\mathrm{H}_{4}$ tidak berpengaruh

Pengujian hipotesis 5 apakah struktur modal, pertumbuhan perusahaan, profitabilitas dan ukuran perusahaan berpengaruh terhadap nilai perusahaan, dapat dilakukan dengan teknik regresi linier berganda. Adapun langkah-langkah yang dilakukan adalah sebagai berikut:

1. Membuat Formulasi Hipotesis:

$\mathrm{H}_{5}: \mathrm{b}_{5} \neq 0$, struktur modal, pertumbuhan perusahaan, profitabilitas dan ukuran perusahaan secara bersama-sama berpengaruh terhadap nilai perusahaan 
2. Menentukan Tingkat Signifikansi

Untuk memperoleh nilai signifikansi, menggunakan taraf nyata ( $\alpha$ ) $5 \%$.

3. Dasar pengambilan keputusan

a. $\rho$-value $<0.05$, maka $\mathrm{H}_{5}$ berpengaruh

b. $\rho$-value $>0.05$, maka $\mathrm{H}_{5}$ tidak berpengaruh

\section{Hasil dan Pembahasan}

Pengujian Hipotesis

Pengujian hipotesis 1 dengan menggunakan anilisis regresi linear sederhana. Pengujian hipotesis 1 dilakukan untuk menguji apakah struktur modal berpengaruh terhadap nilai perusahảan. Hasil pengujian hipotesis dapat dilihat pada tabelberikut ini:

\section{Tabel Nilai R Square Hipotesis 1}

\begin{tabular}{|l|r|r|r|r|}
\hline Model & \multicolumn{1}{|c|}{ M } & R Square & \multicolumn{1}{c|}{$\begin{array}{c}\text { Adjusted R } \\
\text { Square }\end{array}$} & $\begin{array}{c}\text { Std. Error of the } \\
\text { Estimate }\end{array}$ \\
\hline 1 & $.277^{\mathrm{a}}$ & .077 & .074 & 1.20653 \\
\hline
\end{tabular}

a. Predictors: (Constant), Struktur Modal

Sumber: Data Diolah

Nilai $R$ square $\left(\mathrm{R}^{2}\right)$ atau nilai koefisien determinan digunakan untuk mengukur seberapa jauh kemampuan model dalam menerangkan variasi variabel dependen. Nilai $\mathrm{R}^{2}$ adalah diantara nol dan satu. Nilai $\mathrm{R}^{2}$ yang kecil berarti kemampuan variabel independen dalam menjelaskan variasi variabel dependen sangat terbatas. Nilai yang mendekati satu berati variabel independen memberikan hampir semua informasi yang dibutuhkan untuk memprediksi variasi variabel dependen. Nilai $\mathrm{R}^{2}$ sebesar 0.077 mempunyai arti bahwa variabel dependen mampu dijelaskan oleh variabel independen sebesar $7.7 \%$. Dengan kata lain $4.4 \%$ nilai perusahaan mampu dijelaskan variabel struktur modal, sedangkan $92.3 \%$ dijelaskan oleh faktor lain .

Tabel Nilai Hitung Signifikansi Hipotesis 1

ANOVA $^{\mathrm{b}}$

\begin{tabular}{|ll|r|r|r|r|r|}
\hline Model & & Sum of Squares & \multicolumn{1}{c|}{ df } & Mean Square & F & \multicolumn{1}{c|}{ Sig. } \\
\hline 1 & Regression & 38.127 & 1 & 38.127 & 26.192 & $.000^{\mathrm{a}}$ \\
& Residual & 457.091 & 314 & 1.456 & & \\
Total & 495.218 & 315 & & & \\
\hline
\end{tabular}

a. Predictors: (Constant), Struktur Modal

b. Dependent Variable: Nilai Perusahaan

Sumber: Data Diolah

Dari tabel diatas didapat nilai $\mathrm{F}_{\text {hitung }}$ sebesar 26.192 dengan probabilitas 0.000 yang telah menguji pengaruh antara variabel independen (struktur modal) terhadap variabel dependen (nilai perusahaan), karena probabilitas tersebut jauh lebih kecil dari $\alpha 0.05$. Maka dapat dikatakan bahwa struktur modal berpengaruh secara signifikan terhadap nilai perusahaan.

\section{Tabel Model Hipotesis 1}

Coefficients $^{\mathrm{a}}$

\begin{tabular}{|c|c|c|c|c|c|c|}
\hline \multirow{2}{*}{\multicolumn{2}{|c|}{ Model }} & \multicolumn{2}{|c|}{ Unstandardized Coefficients } & $\begin{array}{l}\text { Standardized } \\
\text { Coefficients }\end{array}$ & \multirow[b]{2}{*}{$\mathrm{t}$} & \multirow[b]{2}{*}{ Sig. } \\
\hline & & B & Std. Error & Beta & & \\
\hline \multirow[t]{2}{*}{1} & (Constant) & 1.254 & .070 & & 17.997 & .000 \\
\hline & Struktur Modal & .024 & .005 & .277 & 5.118 & .000 \\
\hline
\end{tabular}

a. Dependent Variable: Nilai Perusahaan

Sumber: Data Diolah 
Dari tabel diatas, dapat dilihat bahwa koefisien dari variabel struktur modal yang positif memberi makna bahwa informasi tentang struktur modal perusahaan di respon searah oleh investor sehingga meningkatkan nilai perusahaan. Dengan demikian, berdasarkan uji hipotesis yang telah dilakukan maka model untuk hipotesis 1 adalah sebagai berikut:

\section{Nilai Perusahaan $=1.254+0.024$ Struktur Modal}

Pengujian hipotesis 2 dilakukan untuk menguji dilakukan untuk menguji apakah pertumbuhan perusahaan berpengaruh terhadap nilai perusahaan. Hasil pengujian hipotesis 2 dapat dilihat pada tabelberikut ini:

Tabel Nilai R Square Hipotesis 2

Model Summary

\begin{tabular}{|l|c|l|r|r|}
\hline Model & R & R Square & $\begin{array}{c}\text { Adjusted R } \\
\text { Square }\end{array}$ & $\begin{array}{c}\text { Std. Error of the } \\
\text { Estimate }\end{array}$ \\
\hline 1 & $.020^{\mathrm{a}}$ & .000 & -.004 & .97877 \\
\hline
\end{tabular}

a. Predictors: (Constant), Pertumbuhan Perusahaan

Sumber: Data Diolah

Nilai $R$ square $\left(\mathrm{R}^{2}\right)$ atau nilai koefisien determinan digunakan untuk mengukur seberapa jauh kemampuan model dalam menerangkan variasi variabel dependen. Nilai $\mathrm{R}^{2}$ adalah diantara nol dan satu. Nilai $R^{2}$ yang kecil berarti kemampuan variabel independen dalam menjelaskan variasi varibel dependen sangat terbatas. Nilai yang mendekati satu berarti variabel indpenden memberikan hampir semua informasi yang dibutuhkan untuk memprediksi variasi variabel dependen. Nilai $\mathrm{R}^{2}$ sebesar 0.000 mempunyai arti bahwa variabel dependen mampu dijelaskan oleh variabel independen sebesar $0 \%$. Dengan kata lain $0 \%$ nilai perusahaan mampu dijelaskan variabel pertumbuhan perusahaan, sedangkan $100 \%$ dijelaskan oleh faktor lain.

\section{Tabel Nilai Hitung Signifikansi Hipotesis 2}

\begin{tabular}{|ll|r|r|r|r|r|}
\hline Model & & Sum of Squares & \multicolumn{1}{|c|}{ df } & Mean Square & \multicolumn{1}{c|}{ F } & \multicolumn{1}{c|}{ Sig. } \\
\hline 1 & Regression & .085 & 1 & .085 & .089 & $.766^{\mathrm{a}}$ \\
& Residual & 220.337 & 230 & .958 & & \\
& Total & 220.422 & 231 & & & \\
\hline
\end{tabular}

a. Predictors: (Constant), Pertumbuhan Perusahaan

b. Dependent Variable: Nilai Perusahaan

Sumber: Data Diolah

Dari tabel didapat nilai $\mathrm{F}_{\text {hitung }}$ sebesar 0.089 dengan probabilitas 0.766 yang telah menguji pengaruh antara variabel independen (pertumbuhan perusahaan) dan variabel dependen (nilai perusahaan), karena probabilitas tersebut jauh lebih besar dari $\alpha 0.05$. Maka dapat dikatakan bahwa pertumbuhan perusahaan tidak berpengaruh terhadap nilai perusahaan.

TabelModel Hipotesis 2

Coefficients $^{\mathrm{a}}$

\begin{tabular}{|c|c|c|c|c|c|c|}
\hline \multirow{2}{*}{\multicolumn{2}{|c|}{ Model }} & \multicolumn{2}{|c|}{$\begin{array}{c}\text { Unstandardized } \\
\text { Coefficients }\end{array}$} & \multirow{2}{*}{\begin{tabular}{c|}
$\begin{array}{c}\text { Standardized } \\
\text { Coefficients }\end{array}$ \\
Beta
\end{tabular}} & \multirow[b]{2}{*}{$\mathrm{t}$} & \multirow[b]{2}{*}{ Sig. } \\
\hline & & B & Std. Error & & & \\
\hline \multirow[t]{2}{*}{1} & (Constant) & 1.281 & .108 & & 11.812 & .000 \\
\hline & Pertumbuhan Perusahaan & .061 & .205 & .020 & .298 & .766 \\
\hline
\end{tabular}

a. Dependent Variable: Nilai Perusahaan

Sumber: Data Diolah

Dari tabel diatas, dapat dilihat bahwa koefisien dari variabel pertumbuhan perusahaan yang positif memberikan makna bahwa informasi tentang pertumbuhan perusahaan dapat direspon searah oleh investor sehingga meningkatkan nilai perusahaan. Dengan demikian, berdasarkan uji hipotesis yang telah dilakukan maka model untuk hipotesis 2 adalah sebagai berikut: 


\section{Nilai Perusahaan $=1.281+0.061$ Pertumbuhan Perusahaan}

Pengujian hipotesis 3 dilakukan untuk menguji pengaruh profotabilitas terhadap nilai perusahaan. Hasil pengujian hipotesis 3 dapat dilihat pada tabel berikut ini:

Tabel Nilai R Square Hipotesis 3

\begin{tabular}{|l|r|r|r|c|}
\hline Model & \multicolumn{1}{|c|}{ R } & R Square & $\begin{array}{c}\text { Adjusted R } \\
\text { Square }\end{array}$ & $\begin{array}{c}\text { Std. Error of the } \\
\text { Estimate }\end{array}$ \\
\hline 1 & $.111^{\mathrm{a}}$ & .012 & .009 & 9.60389245 \\
\hline
\end{tabular}

a. Predictors: (Constant), Profitabilitas

Sumber: Data Diolah

Nilai $R$ square $\left(R^{2}\right)$ atau nilai koefisien determinan digunakan untuk mengukur seberapa jauh kemampuan model dalam menerangkan variasi variabel dependen. Nilai $R^{2}$ adalah diantara nol dan satu. Nilai $R^{2}$ yang kecil berarti kemampuan variabel independen dalam menjelaskan variasi varibel dependen sangat terbatas. Nilai yang mendekati satu berarti variabel indpenden memberikan hampir semua informasi yang dibutuhkan untuk memprediksi variasi variabel dependen. Nilai $\mathrm{R}^{2}$ sebesar 0.009 mempunyai arti bahwa variabel dependen mampu dijelaskan oleh variabel independen sebesar $0.9 \%$. Dengan kata lain $0.9 \%$ nilai perusahaan mampu dijelaskan variabel profitabilitas, sedangkan $99.1 \%$ dijelaskan oleh faktor lain.

Tabel Nilai Hitung Signifikansi Hipotesis 3

ANOVA $^{\mathrm{b}}$

\begin{tabular}{|ll|r|r|r|r|r|}
\hline Model & & Sum of Squares & \multicolumn{1}{c|}{ df } & Mean Square & \multicolumn{1}{c|}{ F } & \multicolumn{1}{c|}{ Sig. } \\
\hline 1 & Regression & 359.413 & 1 & 359.413 & 3.897 & $.049^{2}$ \\
& Residual & 28869.477 & 313 & 92.235 & & \\
Total & 29228.890 & 314 & & & \\
\hline
\end{tabular}

a. Predictors: (Constant), Profitabilitas

c. Dependent Variable: Nilai Perusahaan

Sumber: Data Diolah

Dari tabel didapat nilai $F_{\text {hitung }}$ sebesar 3.897 dengan probabilitas 0.049 yang telah menguji pengaruh antara variabel independen (profitabilitas) dan variabel dependen (nilai perusahaan), karena probabilitas tersebut lebih keci dari $\alpha$ 0.05. Maka dapat dikatakan bahwa profitabilitas berpengaruh terhadap nilai perusahaan.

Tabel Model Hipotesis 3

Coefficients ${ }^{\mathrm{a}}$

\begin{tabular}{|c|c|c|c|c|c|c|}
\hline \multirow{2}{*}{\multicolumn{2}{|c|}{ Model }} & \multicolumn{2}{|c|}{ Unstandardized Coefficients } & \multirow{2}{*}{$\begin{array}{l}\text { Standardized } \\
\text { Coefficients }\end{array}$} & \multirow[b]{2}{*}{$\mathrm{t}$} & \multirow[b]{2}{*}{ Sig. } \\
\hline & & B & Std. Error & & & \\
\hline \multirow[t]{2}{*}{1} & (Constant) & -.286 & 1.566 & & -.183 & .855 \\
\hline & Profitabilitas & 6.393 & 3.239 & .111 & 1.974 & .049 \\
\hline
\end{tabular}

a. Dependent Variable: Nilai Perusahaan

Sumber: Data Diolah

Dari tabel diatas, dapat dilihat bahwa koefisien dari variabel profitabilitas yang positif memberikan makna bahwa informasi tentang profitabilitasdapat direspon searah oleh investor sehingga meningkatkan nilai perusahaan. Dengan demikian, berdasarkan uji hipotesis yang telah dilakukan maka model untuk hipotesis 3 adalah sebagai berikut:

\section{Nilai Perusahaan $=-0.286+6.393$ Profitabilitas}

Pengujian hipotesis 4 dilakukan untuk menguji pengaruh ukuran perusahaan terhadap nilai perusahaan. Hasil pengujian hipotesis 3 dapat dilihat pada tabel berikut ini 
Tabel Nilai R Square Hipotesis 4

Model Summary

\begin{tabular}{|l|r|r|r|l|}
\hline Model & \multicolumn{1}{|c|}{$\mathrm{R}$} & R Square & \multicolumn{1}{c|}{$\begin{array}{c}\text { Adjusted } \mathrm{R} \\
\text { Square }\end{array}$} & $\begin{array}{c}\text { Std. Error of the } \\
\text { Estimate }\end{array}$ \\
\hline 1 & $.233^{\mathrm{a}}$ & .054 & .052 & 10.41805111 \\
\hline
\end{tabular}

a. Predictors: (Constant), Ukuran Perusahaan

Sumber: Data Diolah

Nilai $R$ square $\left(R^{2}\right)$ atau nilai koefisien determinan digunakan untuk mengukur seberapa jauh kemampuan model dalam menerangkan variasi variabel dependen. Nilai $\mathrm{R}^{2}$ adalah diantara nol dan satu. Nilai $R^{2}$ yang kecil berarti kemampuan variabel independen dalam menjelaskan variasi varibel dependen sangat terbatas. Nilai yang mendekati satu berarti variabel indpenden memberikan hampir semua informasi yang dibutuhkan untuk memprediksi variasi variabel dependen. Nilai $\mathrm{R}^{2}$ sebesar 0.054 mempunyai arti bahwa variabel dependen mampu dijelaskan oleh variabel independen sebesar 5.4\%. Dengan kata lain 5.4\% nilai perusahaan mampu dijelaskan variabel ukuran perusahaan, sedangkan $94.6 \%$ dijelaskan oleh faktor lain.

Tabel Nilai Hitung Signifikansi Hipotesis 4

ANOVA $^{b}$

\begin{tabular}{|rl|r|r|r|r|r|}
\hline Model & & Sum of Squares & \multicolumn{1}{c|}{ df } & Mean Square & \multicolumn{1}{c|}{ F } & \multicolumn{1}{c|}{ Sig. } \\
\hline 1 & Regression & 2141.047 & 1 & 2141.047 & 19.727 & $.000^{\mathrm{a}}$ \\
& Residual & 37227.776 & 343 & 108.536 & & \\
Total & 39368.822 & 344 & & & \\
\hline
\end{tabular}

a. Predictors: (Constant), Ukuran Perusahaan

b. Dependent Variable: Nilai Perusahaan

Sumber: Data Diolah

Dari tabel didapat nilai $\mathrm{F}_{\text {hitung }}$ sebesar 19.727 dengan probabilitas 0.000 yang telah menguji pengaruh antara variabel independen (ukuran perusahaan) dan variabel dependen (nilai perusahaan), karena probabilitas tersebut jauh lebih keci dari $\alpha 0.05$. Maka dapat dikatakan bahwa ukuran perusahaan berpengaruh terhadap nilai perusahaan.

Tabel Model Hipotesis 4

Coefficients $^{2}$

\begin{tabular}{|c|c|c|c|c|c|c|}
\hline \multirow{2}{*}{\multicolumn{2}{|c|}{ Model }} & \multicolumn{2}{|c|}{$\begin{array}{c}\text { Unstandardized } \\
\text { Coefficients }\end{array}$} & \multirow{2}{*}{$\begin{array}{c}\begin{array}{c}\text { Standardized } \\
\text { Coefficients }\end{array} \\
\text { Beta } \\
\end{array}$} & \multirow[b]{2}{*}{$\mathrm{t}$} & \multirow[b]{2}{*}{ Sig. } \\
\hline & & $\mathrm{B}$ & Std. Error & & & \\
\hline 1 & (Constant) & 23.764 & 4.736 & & 5.018 & .000 \\
\hline & Ukuran Perusahaan & -1.519 & .342 & -.233 & -4.441 & .000 \\
\hline
\end{tabular}

a. Dependent Variable: Nilai Perusahaan

Sumber: Data Diolah

Dari tabel diatas, dapat dilihat bahwa koefisien dari variabel ukuran perusahaan yang negatif memberikan makna bahwa informasi tentang ukuran perusahaan dapat direspon terbalik oleh investor sehingga meningkatkan nilai perusahaan. Dengan demikian, berdasarkan uji hipotesis yang telah dilakukan maka model untuk hipotesis 4 adalah sebagai berikut:

\section{Nilai Perusahaan $=23.764-1.519$ Ukuran Perusahaan}

Pengujian hipotesis 5 dilakukan untuk menguji pengaruh struktur modal, pertumbuhan perusahaan, profitabilitas dan ukuran perusahaan terhadap nilai perusahaan. Hasil pengujian hipotesis 5 dapat dilihat pada tabel berikut ini: 
Tabel Nilai R Square Hipotesis 5 Model Summary

\begin{tabular}{|l|r|r|r|r|r|}
\hline Model & \multicolumn{1}{|c|}{$\mathrm{R}$} & R Square & $\begin{array}{c}\text { Adjusted } \mathrm{R} \\
\text { Square }\end{array}$ & $\begin{array}{c}\text { Std. Error of the } \\
\text { Estimate }\end{array}$ & Durbin-Watson \\
\hline 1 & $.546^{\mathrm{a}}$ & .298 & .285 & .76067 & 1.976 \\
\hline
\end{tabular}

a. Predictors: (Constant), Ukuran Perusahaan, Struktur Modal, Pertumbuhan Perusahaan, Profitabilitas

b. Dependent Variable: Nilai Perusahaan

Sumber: Data Diolah

Nilai $R$ square $\left(\mathrm{R}^{2}\right)$ atau nilai koefisien determinan digunakan untuk mengukur seberapa jauh kemampuan model dalam menerangkan variasi variabel dependen. Nilai $\mathrm{R}^{2}$ adalah diantara nol dan satu. Nilai $R^{2}$ yang kecil berarti kemampuan variabel independen dalam menjelaskan variasi varibel dependen sangat terbatas. Nilai yang mendekati satu berarti variabel indpenden memberikan hampir semua informasi yang dibutuhkan untuk memprediksi variasi variabel dependen. Nilai $\mathrm{R}^{2}$ sebesar 0.298 mempunyai arti bahwa variabel dependen mampu dijelaskan oleh variabel independen sebesar $29.8 \%$. Dengan kata lain $29.8 \%$ nilai perusahaan mampu dijelaskan variabel struktur modal, pertumbuhan perusahaan, profitabilitas dan ukuran perusahaan, sedangkan $70.2 \%$ dijelaskan oleh faktor lain yang tidak diikutkan dalam penelitian ini.

Tabel Nilai Hitung Signifikansi Hipotesis 5

\begin{tabular}{|ll|r|r|r|c|c|}
\hline Model & & Sum of Squares & \multicolumn{1}{c|}{ df } & Mean Square & F & \multicolumn{1}{c|}{ Sig. } \\
\hline 1 & Regression & 54.986 & 4 & 13.747 & 23.758 & $.000^{\mathrm{a}}$ \\
& Residual & 129.610 & 224 & .579 & & \\
& Total & 184.596 & 228 & & & \\
\hline
\end{tabular}

a. Predictors: (Constant), Ukuran Perusahaan, Struktur Modal, Pertumbuhan Perusahaan, Profitabilitas

b. Dependent Variable: Nilai Perusahaan

Sumber: Data Diolah

Dari tabel didapat nilai $F_{\text {hitung }}$ sebesar 23.758 dengan probabilitas 0.000 yang telah menguji pengaruh antara variabel independen (struktur modal, pertumbuhan perusahaan, profitabilitaas dan ukuran perusahaan) dan variabel dependen (nilai perusahaan), karena probabilitas tersebut jauh lebih keci dari $\alpha$ 0.05. Maka dapat dikatakan bahwa struktur modal, pertumbuhan perusahaan, profitabilitaas dan ukuran perusahaan berpengaruh terhadap nilai perusahaan.

Tabel Model Hipotesis 5

Coefficients $^{\mathrm{a}}$

\begin{tabular}{|c|c|c|c|c|c|c|}
\hline & & \multicolumn{2}{|c|}{$\begin{array}{l}\text { Unstandardized } \\
\text { Coefficients }\end{array}$} & $\begin{array}{l}\text { Standardized } \\
\text { Coefficients } \\
\end{array}$ & \multirow[b]{2}{*}{$\mathrm{t}$} & \multirow[b]{2}{*}{ Sig. } \\
\hline \multicolumn{2}{|c|}{ Model } & $\mathrm{B}$ & Std. Error & Beta & & \\
\hline 1 & (Constant) & -1.281 & .502 & & -2.550 & .011 \\
\hline & Struktur Modal & .481 & .062 & .438 & 7.741 & .000 \\
\hline & Pertumbuhan Perusahaan & -.115 & .173 & -.038 & -.667 & .506 \\
\hline & Profitabilitas & 2.071 & .318 & .368 & 6.513 & .000 \\
\hline & Ukuran Perusahaan & .072 & .032 & .125 & 2.222 & .027 \\
\hline
\end{tabular}

a. Dependent Variable: Nilai Perusahaan

Sumber: Data Diolah 
Dari tabel diatas, dapat dilihat bahwa koefisien dari variabel struktur modal, profitabilitas, ukuran perusahaan yang positif memberikan makna bahwa informasi tentang variabel tersebut direspon searah oleh investor sedangkan pertumbuhan perusahaan yang negatif memberikan makna bahwa informasi tentang pertumbuhan perusahaan dapat direspon terbalik oleh investor sehingga meningkatkan nilai perusahaan. Dengan demikian, berdasarkan uji hipotesis yang telah dilakukan maka model untuk hipotesis 5 adalah sebagai berikut:

$$
\begin{aligned}
\text { Nilai Perusahaan } & =-1.281+0.481 \text { Struktur Modal }-0.115 \text { Pertumbuhan Perusahaan } \\
& +2.071 \text { Pr ofitabilitas }+0.072 \text { Ukuran Perusahaan }
\end{aligned}
$$

Pembahasan ,

Pengaruh struktur Modal Terhadap Nilai Perusahaan

Hasil penelitian ini menunjukkan bahwa struktur modal berpengaruh secara positif terhadap nilai perusahaan, yang dapat dilihat dari nilai koefisien regresi struktur modal sebesar 0.024 dengan signifikansi 0.000 , yang berarti bahwa setiap adanya kenaikan hutang sebagai sumber pendanaan perusahaan sebesar 1 satuan akan berpengaruh pada peningkatan nilai perusahaan sebesar 0.024 satuan. Hasil temuan ini terbukti menerima hipotesis $1\left(\mathrm{H}_{1}\right)$ yang menyatakan bahwa struktur modal berpengaruh terhadap nilai perusahaan,dan sekaligus menjawab perumusan masalah pertama penelitian ini.

Hasil penelitian ini konsisten dengan temuan yang dilakukan oleh solihah dan taswan (2002), yang menyatakan bahwa kebijakan hutang berpengaruh positif namun tidak signiifikan terhadap nilai perusahaan pada perusahaan manufaktur yang go publik di Bursa Efek Jakarta periode tahun 1993-1997 atau secara tepatnya terjadi sebelum krisis moneter dan pada awal krisis moneter.

Hasil penelitian ini konsisten dengan temuan Hasnawati (2005), yang menyatakan bahwa secara parsial keputusan pendanaan berpengaruh positif terhadap nilai perusahaan namun tidak signifikan pada 259 perusahaan di Jakarta Stock Exchange dengan periode penelitian 2001.

Hasil penelitian ini juga sejalan dengan Trade-Off Theory yang menyatakan bahwa (dengan asumsi titik target struktur modal belum optimal) peningkatan rasio hutang pada struktur modal akan meningkatkan nilai perusahaan. Dengan demikian, teori tersebut menjelaskan bahwa ketika struktur modal berada diatas target titik optimum maka setiap peningkatan hutang akan meningkatkan nilai perusahaan. Berdasarkan bukti empiris bahwa rata-rata penggunaan hutang pada periode penelitian 2007 sampai dengan tahun 2009 sudah sangat tinggi sekali yang ditunjuki oleh rasio DER dari tahun 2004 sampai tahun 2006 rata-rata sampel sebesar 2.207 dan meningkat terus sampai 2.377 , meskipun belum ada karakteristik tertentu untuk titik optimum penggunaan hutang dari struktur modal suatu perusahaan, namun berdasarkan penelitian Sugihen (2003:208) titik optimum struktur modal berkisar antara 0.3 sampai 0.4 . Dengan demikian, penelitian ini menggunakan panduan angka tersebut untuk titik optimum penggunaan hutang dari struktur modal.

Total hutang tahun 2007 dibandingkan dengan total hutang tahun 2009 meningkat 123\% (lihat tabel pengamatan) dan diikuti dengan peningkatan nilai ekuitas perusahaan tahun 2009 tercatat $135 \%$ dari nilai ekuitas tahun 2007. Peningkatan total aset sampai dengan tahun 2009 diduga adanya penambahan investasi yang dilakukan perusahaan. 
Tabel Pengamatan Hutang, Ekuitas, Aset, Penjualan, Harga Pokok Penjualan, Jumlah Lembar Saham Yang Beredar

\begin{tabular}{|c|c|c|c|c|}
\hline \multirow{2}{*}{ Keterangan } & \multicolumn{3}{|c|}{ Tahun } & \multirow{2}{*}{$\begin{array}{c}\text { Prosentase } \\
(\%)\end{array}$} \\
\hline & 2007 & 2008 & 2009 & \\
\hline Total Debt & 231.787 .792 & 299.170 .254 & 285.873 .612 & $123 \%$ \\
\hline Total Equity & 136.364 .090 & 157.225 .996 & 184.638 .264 & $135 \%$ \\
\hline Total Aset & 382.865 .162 & 456.396 .250 & 470.511 .876 & $123 \%$ \\
\hline Total Penjualan & 359.560 .724 & 490.285 .125 & 487.505 .889 & $136 \%$ \\
\hline Total Harga Pokok Penjualan & 273.584 .573 & 383.765 .752 & 370.564 .126 & $135 \%$ \\
\hline Jumlah Lembar Saham Yang Beredar & 226.778 .818 .207 & 215.206 .868 .086 & 217.733 .505 .254 & 96 \\
\hline Equity Pershare & 238.018 & 262.290 & 271.687 & $114 \%$ \\
\hline Struktur Modal & 253,8329451 & 419,1089752 & 273,4460177 & $108 \%$ \\
\hline Pertumbuhan Perusahaan & 29,73367431 & 24,52919608 & $-0,749533358$ & $-3 \%$ \\
\hline Profitabilitas & 25,74916191 & 21,34136799 & 12,12329688 & $47 \%$ \\
\hline Ukuran Perusahaan & 1571,782469 & 1587,337109 & 1585,124993 & $101 \%$ \\
\hline Nilai Perusahaan & 373,5529184 & 224,7672606 & 395,0330788 & $106 \%$ \\
\hline Rata-Rata Total Debt & 3.996 .341 & 5.158 .108 & 4.928 .855 & $123 \%$ \\
\hline Rata-Rata Total Equity & 2.351 .105 & 2.710 .793 & 3.183 .418 & $135 \%$ \\
\hline Rata-Rata Total Aset & 6.601 .123 & 7.868 .901 & 8.112 .274 & $123 \%$ \\
\hline Rata-Rata Total Penjualan & 6.199 .323 & 8.453 .192 & 8.405 .274 & $136 \%$ \\
\hline $\begin{array}{l}\text { Rata-Rata Total Harga Pokok } \\
\text { Penjualan }\end{array}$ & 4.716 .975 & 6.616 .651 & 6.389 .037 & $135 \%$ \\
\hline $\begin{array}{l}\text { Rata-Rata Jumlah Lembar Saham } \\
\text { Yang Beredar }\end{array}$ & 3.909 .979 .624 & 3.710 .463 .243 & 3.754 .025 .953 & $96 \%$ \\
\hline Rata-Rata Equity Pershare & 4.104 & 4.522 & 4.684 & $114 \%$ \\
\hline Rata-Rata Struktur Modal & 2,207243001 & 3,644425871 & 2,377791459 & $108 \%$ \\
\hline Rata-Rata Pertumbuhan Perusahaan & 0,25855369 & 0,213297357 & $-0,006517681$ & $-3 \%$ \\
\hline Rata-Rata Profitabilitas & 0,223905756 & 0,185577113 & 0,105419973 & $47 \%$ \\
\hline Rata-Rata Ukuran Perusahaan & 13,66767365 & 13,80293138 & 13,7836956 & $101 \%$ \\
\hline Rata-Rata Nilai Perusahaan & 3,248286247 & 1,954497918 & 3,43507025 & $106 \%$ \\
\hline
\end{tabular}

Sumber: Data diolah

Bukti empiris penelitian ini membuktikan bahwa pengaruh secara langsung dan positif antara struktur modal terhadap nilai perusahaan terjadi tahun 2007 sampai dengan tahun 2009 meskipun pengaruh antara struktur modal terhadap nilai perusahaan adalah lemah.

\section{Pengaruh Pertumbuhan Perusahaan Terhadap Nilai Perusahaan}

Hasil penelitian ini menunjukkan bahwa pertumbuhan perusahaan berpengaruh positif namun tidak signifikan terhadap nilai perusahaan, yang dapat dilihat dari nilai koefisien regresi pertumbuhan perusahaan sebesar 0.061 dengan signifikansi 0.766 , yang berarti bahwa setiap peningkatan pertumbuhan perusahaan sebesar 1 satuan maka akan berpengaruh pada peningkatan 
nilai perusahaan sebesar 0.061 satuan. Namun peningkatan pertumbuhan perusahaan tersebut tidak mempengaruhi pergerakan nilai perusahaan di kalangan investor.

Hasil temuan ini terbukti menolak hipotesis $2\left(\mathrm{H}_{2}\right)$ yang menyatakan bahwa pertumbuhan perusahaan berpengaruh terhadap nilai perusahaan, dan sekaligus menjawab rumusan masalah kedua penelitian ini.

Hasil temuan ini tidak konsisten dengan temuan yang dilakukan oleh Sriwardany (2006) yang menemukan bahwa pertumbuhan perusahaan mempunyai pengaruh langsung dan positif terhadap perubahan harga saham pada perusahaan manufaktur yang terdaftar di Bursa Efek Jakarta periode 2000-2004 dengan 156 perusahaan.

Hasil temuan ini konsisten dengan temuan yang dilakukan oleh Safrida (2008) yang menemukan bahwa pertumbuhan perusahaan tidak berpengaruh terhadap nilai perusahaan pada perusahaan manufaktur di Bursa Efek Jakarta periode 2004-2007 dengan 45 perusahaan.

Tabel pengamatan diatas menunjukkan bahwa total hutang tahun 2007 dibandingkan dengan total hutang tahun 2009 meningkat menjadi 123\% dan diikuti dengan peningkatan nilai ekuitas yang dimiliki perusahaan pada tahun 2009 yang tercatat 135\% dari tahun 2007.

\section{Pengaruh Profitabilitas Terhadap Nilai Perusahaan}

Hasil penelitian ini menunjukkan bahwa profitabilitas berpengaruh positif dan signifikan terhadap nilai perusahaan, yang dapat dilihat dari nilai koefisien regresi profitabilitas sebesar 6.393 dengan signifikansi 0.049 , yang berarti bahwa setiap adanya kenaikan profitabilitas sebesar 1 satuan akan berpengaruh pada peningkatan nilai perusahaan sebesar 6.393 satuan. Hasil temuan ini terbukti menerima hipotesis $3\left(\mathrm{H}_{3}\right)$ yang menyatakan bahwa profitabilitas berpengaruh terhadap nilai perusahaan, dan sekaligus menjawab perumusan masalah ketiga penelitian ini.

Hasil temuan ini konsisten dengan temuan yang dilakukan oleh Rahmawati dan Akram (2004) yang menemukan bukti bahwa profitabilitas berpengaruh positif terhadap nilai perusahaan, yang memberikan arti bahwa terjadi kenaikan penjualan yang di tunjukkan dengan meningkatnya GPM (Gross Profit Margin), maka akan semakin baik kemampuan perusahaan untuk menghasilkan dan meningkatkan pendapatan, sehingga nilai perusahaan pun meningkat.

Tabel pengamatan diatas menunjukkan bahwa total penjulan perusahaan tahun 2009 dibandingakn tahun 2007 meningkat menjadi 136\% dan diikuti dengan peningkatan harga pokok penjualan yang dimiliki perusahaan pada tahun 2009 yang tercatat 135\% dari tahun 2007 .

\section{Pengaruh Ukuran Perusahaan Terhadap Nilai Perusahaan}

Hasil penelitian ini menunjukkan bahwa ukuran perusahaan berpengaruh negatif terhadap nilai perusahaan, yang dapat dilihat dari koefisien regresi ukuran perusahaan sebesar 1.519 dengan signifikansi 0.000 , yang berarti bahwa setiap adanya penurunan ukuran perusahaan sebesar 1 satuan maka akan berpengaruh pada peningkatan nilai perusahaan sebesar 1.519 satuan. Hasil temuan ini terbukti menerima hipotesis $4\left(\mathrm{H}_{4}\right)$ yang menyatakan bahwa ukuran perusahaan berpengaruh terhadap nilai perusahaan, dan sekaligus menjawab perumusan masalah keempat penelitian ini.

Hasil temuan ini tidak konsisten dengan temuan yang dilakukan Rahmawati dan Akram (2004) yang menyatakan bahwa ukuran perusahaan berpengaruh negatif terhadap nilai perusahaan tapi tidak signifikan.

Tabel pengamatan diatas menunjukkan bahwa total aktiva tahun 2007 dibandingkan total aktiva tahun 2009 meningkat $123 \%$ dan diikuti dengan peningkatan pada ukuran perusahaan sebesar 101\% pada tahun 2009 dibandingkan dengan tahun 2007.

\footnotetext{
Pengaruh Struktur Modal, Pertumbuhan Perusahaan, Profitabilitas dan Ukuran Perusahaan Terhadap Nilai Perusahaan

Hasil penelitian ini menunjukkan bahwa struktur modal, pertumbuhan perusahaan, profitabilitas dan ukuran perusahaan berpengaruh terhadap nilai perusahaan, yang dapat dilihat dari koefisien regresi struktur modal 0.481 , pertumbuhan perusahaan -0.115 , profitabilitas 2.071 dan ukuran perusahaan 0.072 dengan signifikansi 0.000 , yang berarti bahwa setiap ada kenaikan struktur modal sebesar 1 satuan maka akan berpengaruh pada peningkatan nilai perusahaan sebesar 0.481 , setiap ada penurunan pertumbuhan perusahaan sebesar 1 satuan maka akan berpengaruh
} 
pada peningkatan nilai perusahaan sebesar 0.115 , setiap ada kenaikan profitabilitas sebesar 1 satuan maka akan berpengaruh pada peningkatan nilai perusahaan sebesar 2.071 dan setiap ada kenaikan ukuran perusahaan sebesar 1 satuan maka akan berpengaruh pada peningkatan nilai perusahaan sebesar 0.072 .

Hasil temuan ini terbukti menerima hipotesis $5\left(\mathrm{H}_{5}\right)$ yang menyatakan bahwa struktur modal, pertumbuhan perusahaan, profitabilitas dan ukuran perusahaan berpengaruh signifikan terhadap nilai perusahaan.

Perubahan nilai perusahaan pada perusahaan manufaktur diperkirakan adanya perubahan nilai hutang, nilai ekuitas, nilai total aktiva, nilai penjualan, harga pokok penjualan, dan ukuran perusahaan. Nilai perusahaan meningkat pada tahun 2009 sebesar 395,03 jika dibandingkan tahun 2007 yang hanya 373,55. Artinya ada peningkatan nilai perusahaan pada tahun 2009 sebesar 106\% jika dibandingkan nilai perusahaan tahun 2007. Besarnya perubahan rata-rata nilai perusahaan tersebut dipengaruhi meningkat penggunaan hutang perusahaan, meningkatnya nilai ekuitas perusahaan, meningkatnya total aktiva, maningkatnya harga pokok penjualan, meningkatnya jumlah lembar saham yang beredar.

\section{Simpulan}

Dari hasil analisis dan pembahasan dapat diambil beberapa kesimpulan sebagai berikut:

1. Struktur modal berpengaruh positif dan signifikan terhadap nilai perusahaan. Hal ini berarti bahwa perusahaan lebih banyak menggunakan ekuitas sebagai sumber penggunaan dana daripada menggunakan hutang sehingga berpengaruh pada peningkatan nilai perusahaan.

2. Pertumbuhan perusahaan berpengaruh positif namun tidak signifikan terhadap nilai perusahaan. Hal ini berarti setiap peningkatan perubahan total aktiva periode penelitian tidak mempengaruhi harga saham terhadap ekuitas perlembar saham dikalangan investor.

3. Profitabilitas berpengaruh positif dan signifikan terhadap nilai perusahaan. Hal ini berarti bahwa terjadi kenaikan penjualan yang ditunjukkan dengan meningkatkannya Gross Profit Margindan setiap terjadi peningkatan tersebut akan meningkatnya pula nilai perusahaan.

4. Ukuran perusahaan berpengaruh negatif dan signifikan terhadap nilai perusahaan. Hal ini berarti setiap penurunan ukuran perusahaan akan berpengaruh pada peningkatan nilai perusahaan.

5. Struktur modal, pertumbuhan perusahaan, profitabilitas, ukuran perusahaan berpengaruh terhadap nilai perusahaan. Hal ini berarti bahwa penggunaan ekuitas sebagai sumber pendanaan perusahaan, penurunan perubahan total aktiva, peningkatan penjualan perusahaan, kenaikan total aktiva akan meningkatnya nilai perusahaan.

\section{Keterbatasan}

1. Penelitian ini hanya terbatas pada perusahaan manufaktur yang terdaftar di Bursa Efek Indonesia dengan periode penelitian tahun 2006-2009.

2. Penelitian ini hanya meneliti empat variabel independen dan satu variabel dependen. Di perkirakan ada variabel independen ain yang mempengaruhi nilai perusahaan

3. Penelitian ini tidak lebih lanjut membahas kegiatan investasi dari perusahaan.

\section{Saran}

Berdasarkan kesimpulan dan keterbatasan penelitian, maka perlu dilakukan penyempurnakan terhadap penelitian yang dilakukan. Adapun saran untuk peneliti selanjutnya adalah sebagai berikut:

1. Untuk peneliti lanjutan disarankan untuk menggunakan sampel jenis seluruh di Bursa Efek Indonesia, dan periode penelitian lebih panjang agar mendapatkan hasil yang lebih digeneralisir.

2. Untuk peneliti lanjutan dapat menambahkan variabel lain seperti kepemilikan manajerial, ukuran perusahaan serta perubahan nilai valuta asing yang diprediksi bisa mempengaruhi dari nilai perusahaan.

3. Bagi pihak investor, hendaknya dalam melakukan investasi mempertimbangkan struktur modal perusahaan, tingkat pertumbuhan perusahaan, tingkat profitabilitas, dan ukuran 
perusahaan. Hal ini perlu dipertimbangkan agar pihak investor pun dalam melakukan investasi dapat menerima return yang baik.

\section{Daftar Pustaka}

Arief, Sritua. 2006. Metodologi Penelitian Ekonomi. Jakarta: UI Press.

Arifin, Zaenal. 2005. Teori Keuangan dan Pasar Modal. Edisi Pertama. Yogyakarta: Ekonisia.

Brigham, E.F., dan J. Houston. 2001. Manajemen Keuangan.Penerjemah Hermawan Wibowo. Edisi Kedelapan. Edisi Indonesia. Buku II. Jakarta: Erlangga.

Brigham, E.F., and L.C. Gapenski. 1988. Financial Management Theory and Practice. Fifth Edition. United State Of America.

Driffeild, N., V.Mahambare, and S.Pal. 2007. "How Does Ownership Structure Affect Capital Structure and Firm Value? Recent Evidence From East Asia". www.google.com/searchtanggal 15 Juni 2011

Fama, E.F. 1978. "The Effects Of a Firm's Investment and Financing Decisions on The Welfare of Its Security Holders". The Modern Theory Of Corporate Finance; Vol 68. No.3, pp. 22-38.

Fama, E.F., dan K.R.French.1998. "Taxes, Financing Decision, and Firm Value". The Journal of Finance;Vol.LIII. No.3, June, PP.819-843.

Hakim, Abdul. 2004. Statistik Deskriptif Untuk Ekonomi dan Bisnis. Cetak Kedua. Yogyakarta: Ekonisia.

Hasnawati, Sri. 2005. "Implikasi Keputusan Investasi, Pendanaan, dan Dividen Terhadap Nilai Perusahaan Perusahaan Publik Di Bursa Efek Jakarta". Usahawan: No.09/Th XXXIX, September 2005.

Helfert, E.A. 1997. Teknik Analisis Keuangan. Penerjemah Herman Wibowo. Edisi Kedelapan. Jakarta: Erlangga.

Husnan, S., dan E. Pudjiastuti. 2004. Dasar-Dasar Manajemen Keuangan. Edisi Keempat. Yogyakarta: UUP AMP YKPN.

Jensen, M.C. 2001. "Value Maximization, Stakeholders Theory, and The Corporate Objective Function". Working Paper; No.01-09. Harvard Business School, PP.1-21. or www.google.com/search tanggal 15 Juni 2011.

Kallapur, S., dan M.A. Trombley. 1999. "The Association Between Investment Opportunity Set Proxies and Realized Growth". Journal Of Business \& Accounting. 26 April/May. Pp.505519. or www.google.com/searchtanggal 15 Juni 2011.

Machfoedz, Mas'ud. 1996. Akuntansi Manajemen Perencanaan Dan Pembuatan Keputusan Jangka Pendek. Edisi Kelima. Buku 1. Yogyakarta: STIE-WIDYA WIWAHA.

Rahwati, Intan., dan Akram. 2007. "Faktor-Faktor Yang Mempengaruhi Kebijakan Deviden dan Pengaruhnya Terhadap Nilai Perusahaan Pada Perusahaan-Perusahaan di Bursa Efek Jakarta Periode 2000-2004". Jurnal Riset Akuntansi AKSIOMA Vol.6, Hal 42 No.1 Juni 2007. or www.google.com/searchtanggal 15 Juni 2011.

Riyanto, Bambang. 1999. Dasar-Dasar Pembelanjaan Perusahaan. Edisi 4. Yogyakarta: BPFE.

Safrida, Eli. 2008. "Pengaruh Struktur Modal dan Pertumbuhan Perusahaan Terhadap Nilai Perusahaan Pada Perusahaan Manufaktur Di Bursa Efek Jakarta". Tesis.

Santoso, Singgih. 2006. Menguasai Statistik Di Era Informasi Dengan SPSS 15. Jakarta: Elex Media Komputindo.

Sartono, R.A. 2001. Manajemen Keuangan Teori dan Aplikasi. Edisi 4. Yogyakarta: BPFE.

Shin, H.H., dan R.M. Stulz. 2002."Firm Value, Risk, and Growth Opportunities". Banking and Monetory Economics at The Ohio State University, and Reseach, hal.1-35. or www.google.com/searchtanggal 15 Juni 2011.

Soliha, E., dan Taswan. 2002. "Pengaruh Kebijakan Hutang Terhadap Nilai Perusahaan Serta Beberapa Faktor Yang Mempengaruhinya". Jurnal Bisnis Dan Ekonomi. September 2002. or www.google.com/searchtanggal 15 Juni 2011.

Sriwardany. 2006. "Pengaruh Pertumbuhan Perusahaan Terhadap Kebijakan Struktur Modal dan Dampaknya Terhadap Perubahan Harga Saham Pada Perusahaan Manufaktur Tbk". Tesis.

Stulz, R.M. 1990."Managerial Discreation and Optimal Financing Policies". Journal Of Financial Economics. Vol.26, Hal: 3-27. or www.google.com/searchtanggal 15 Juni 2011. 
Sugihen, S.G. 2003. "Pengaruh Struktur Modal Terhadap Produktivitas Aktiva, Kinerja Keuangan, Serta Nilai perusahaan Industri Manufaktur Terbuka Di Indonesia”. Disertasi.

Susanto. 1997. Manajemen Aktual Topik-Topik Aktual Manajemen Dalam Riak Perubahan. Jakarta: Grasindo.

Umar, Husein. 2000. Metode Penelitian Untuk Skripsi dan Tesis Bisnis. Cetak 3. Jakarta: Raja Grafindo Persada.

Wahyudi, U., dan H.P. "Pawestri. 2006. Implikasi Struktur Kepemilikan Terhadap Nilai Perusahaan: Dengan Keputusan Keuangan Sebagai Variabel Intervening". Simposium Nasional Akuntansi 9 Padang. K-AKPM 17.

Weston, J.F., dan E.F. Brigham. 1985. Manajemen Keuangan. Penerjemah Djoerban Wahid. Edisi Ketujuh. Jilid II. Jakarta: Erlangga.

Winardi. 2001. Ekonomi Manajerial. Bandung: Mandar Maju. 